\title{
Advances in the management of squamous cell carcinoma of the head and neck
}

\author{
Jean-Pascal Machiels*, Maarten Lambrecht, François-Xavier Hanin, \\ Thierry Duprez, Vincent Gregoire, Sandra Schmitz and Marc Hamoir
}

Address: Clinique de cancérologie cervico-maxillo-faciale, Centre du cancer et d'hématologie, Cliniques universitaires Saint-Luc and Institut de Recherche Clinique et Expérimentale (IREC), Université catholique de Louvain, 10 Avenue Hippocrate, 1200 Brussels, Belgium

* Corresponding author: Jean-Pascal Machiels (jean-pascal.machiels@uclouvain.be)

Fl000Prime Reports 2014, 6:44 (doi:10.12703/P6-44)

All FI000Prime Reports articles are distributed under the terms of the Creative Commons Attribution-Non Commercial License (http://creativecommons.org/licenses/by-nc/3.0/legalcode), which permits non-commercial use, distribution, and reproduction in any medium, provided the original work is properly cited.

The electronic version of this article is the complete one and can be found at: http://f $1000 . c o m / p r i m e /$ reports/m/6/44

\begin{abstract}
Squamous cell carcinoma of the head and neck (SCCHN) is the sixth most common cancer worldwide. The main risk factors for cancers of the oral cavity, larynx, oropharynx, and hypopharynx are alcohol and tobacco use. In addition, the human papillomavirus (HPV) is an established cause of oropharyngeal cancer. An experienced multidisciplinary team is necessary for adequate management and optimal outcome. The treatment of locally advanced disease generally requires various combinations of radiotherapy, surgery, and systemic therapy, but despite this aggressive multimodal treatment, $40 \%$ to $60 \%$ of the patients will relapse. In this report, we will discuss recent advances in the management of SCCHN, including new developments in molecular biology, imaging, and treatment.
\end{abstract}

\section{Introduction}

SCCHN is the sixth most common cancer worldwide; approximately 600,000 new cases are diagnosed per year worldwide [1]. SCCHN generally begins in the mucosal surfaces of the head and neck. The most frequent tumor sites of SCCHN are the larynx, the pharynx, and the oral cavity. Head and neck cancers also include salivary gland tumors as well as nasopharyngeal cancer and paranasal and nasal sinus cancer. These tumors are less frequent and will not be discussed in this report.

Consumption of alcohol or tobacco is the main risk factor for cancers of the oral cavity, larynx, oropharynx, and hypopharynx and accounts for $75 \%$ of SCCHN. The oncogenic HPV infection, mainly HPV-16, is an established cause of oropharyngeal cancer (predominantly tonsils and base of tongue) [2,3]. Globally, the incidence of HPVinduced oropharyngeal cancer increases each year, but varies from less than $10 \%$ to $70 \%$ of all oropharyngeal cancers, depending on the geographic area, being more frequent in industrialized countries [4-6]. The etiologic role of HPV in SCCHN sites other than oropharynx is unclear.
The treatment choice depends on the location of the primary tumor, the stage of the disease, and the expected oncological and functional outcomes. American Joint Committee on Cancer (AJCC) early-stage (I/II) SCCHN is usually treated with single-modality therapy (i.e. surgery or radiotherapy [RT]). The management of locally advanced disease (AJCC stage III/IV) generally requires various combinations of RT, surgery, and chemotherapy or cetuximab. The survival rates for all patients with SCCHN are approximately $40 \%$ to $60 \%$ at 5 years [7]. In this report, we review recent advances in the management of SCCHN, including new developments in molecular biology, imaging, and treatment.

\section{Clinical relevance of SCCHN molecular biology}

The epidermal growth factor receptor (EGFR) is a transmembrane tyrosine kinase receptor belonging to the HER/erbB family and is overexpressed in up to $90 \%$ of SCCHN [8]. High EGFR gene copy number has been reported in $10 \%$ to $58 \%$ of SCCHN [9-12]. In SCCHN, in contrast to lung cancer, activating EGFR 
mutations are rare. Overexpression of EGFR and high EGFR gene copy number are associated with poor prognosis and radioresistance [9-17]. The EGFR is a relevant target in SCCHN since cetuximab, an immunoglobulin G1 (IgG1) monoclonal antibody targeting the EGFR, improves overall survival (OS) when combined with RT or chemotherapy $[18,19]$. However, only a minority of patients will benefit from antiEGFR monoclonal antibodies, and the objective response rate in monotherapy is between $6 \%$ and $13 \%[20,21]$.

Recently, deep sequencing technology has allowed a better characterization of the implicated genes [22-24]. Somatic mutations in TP53 (47\% to 72\%), NOTCH1 (14\% to $19 \%$ ), CDKN2A (9\% to $22 \%$ ), PIK3CA (6\% to $21 \%)$, FBXW7 (5\%), HRAS (4\% to $8 \%)$, FAT1 (23\%), and CASP8 (8\%) have been reported. Besides these mutations, some genes or their related proteins have been found to be altered by other mechanisms (amplification, deletion, epigenetic) [25-29]. Altogether, activating mutations in classic oncogenes seem relatively rare in SCCHN and most of the genetic alterations occur in tumor suppressor genes. These findings are important for the further development of novel therapies for SCCHN, although developing new compounds to restore the activity of altered tumor suppressor genes like $p 53$ or $C D K N 2 A$ is extremely challenging.

Most of the genetic alterations described above have been found in $\mathrm{HPV}^{-}$tumors. Biologically, HPV-induced SCCHN is different and is characterized by the inactivation of the p53 tumor suppressor gene by the viral oncoprotein E6 and the retinoblastoma suppressor gene by the HPV oncoprotein E7 [30,31] (Figure 1). Globally, $\mathrm{HPV}^{+}$tumors have fewer genetic alterations than $\mathrm{HPV}^{-}$tumors $[24,32]$. Interestingly, activation of the phosphoinositide 3-kinase (PI3K) pathway appears quite frequent in $\mathrm{HPV}^{+}$tumors [33]. Many studies have shown that patients with $\mathrm{HPV}^{+}, \mathrm{p} 16^{+}$, or $\mathrm{p} 53$ wild-type tumors have better OS and progression-free survival (PFS) rates than patients with $\mathrm{HPV}^{-}, \mathrm{p} 16^{-}$, or p53 altered SCCHN [34-36]. Ang and colleagues classified patients with SCCHN as having a low, intermediate, or high risk of death on the basis on four factors: HPV status, pack-years of tobacco smoking, tumor stage, and nodal stage [2]. Therefore, it is crucial that future clinical trials select or at least stratify patients according to their HPV and risk status. Since the prognosis for patients with $\mathrm{HPV}^{+}$is better, specific trials investigating treatment de-intensification in this population are ongoing. However, today without the results of these trials, $\mathrm{HPV}^{+}$tumors must be treated with the same regimens as $\mathrm{HPV}^{-}$tumors.
Figure I. Molecular biology of human papillomavirus (HPV)positive squamous cell carcinoma of the head and neck (SCCHN)

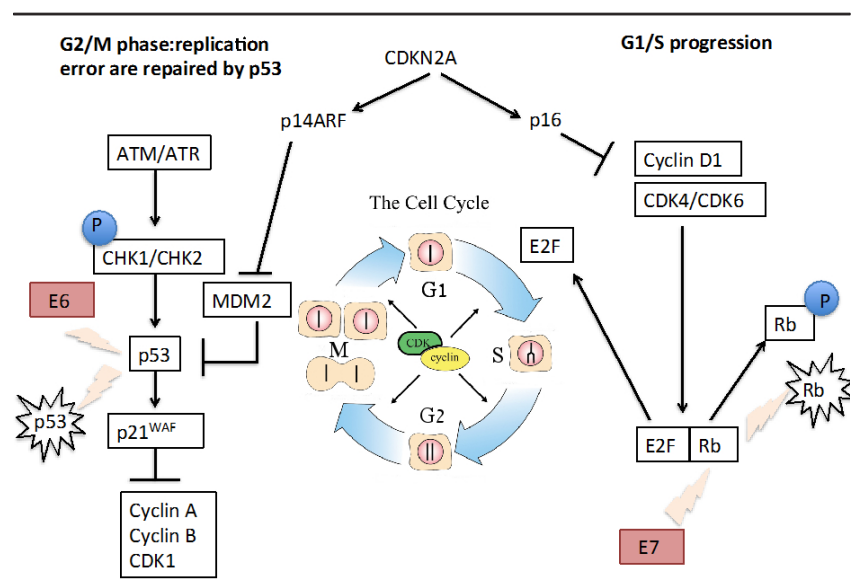

HPV-induced SCCHN is characterized by the inactivation of the p53 tumor suppressor gene by the viral oncoprotein $\mathrm{E} 6$ and the retinoblastoma $(\mathrm{Rb})$ suppressor gene by the HPV oncoprotein E7. Inactivation of the Rb gene induces the release of the E2F transcriptional factor that leads to cell cycle progression $(G$ to $S$ phase). Inactivation of $p 53$ removes the break of $p 21$ on cyclin-dependent kinase (CDK) activity. All together, these molecular alterations lead to cell cycle progression and cell division.

\section{Challenges and perspectives in imaging work-up \\ 2.I. Positron emission tomography}

Positron emission tomography (PET) is a non-invasive procedure using tracers labeled with positron emitters such as fluorine-18. The most frequently used tracer in clinical practice is ${ }^{18} \mathrm{~F}$-fluorodeoxyglucose (FDG), an analog of glucose, allowing metabolic mapping of the entire body in one procedure. In the last decade, all manufacturers have developed PET cameras coupled with conventional computerized tomography (CT) scanners (PET-CT), allowing instant fusion of anatomical and metabolic images, leading to better anatomic localization of lesions and increasing accuracy [37].

In head and neck cancers, some controversies have arisen about some specific indications [38]. There is a large consensus for the role of PET in the detection of occult primary SCCHN, staging and restaging of patients with high-risk of disseminated disease, and the assessment of lesions of unknown origin [39-41].

In addition, PET has an increasing role in therapy response assessment after chemoradiotherapy (CRT) in SCCHN, showing a high negative predictive value in neck evaluation when performed 12-weeks after completion of treatment [42-44]. This post-therapy evaluation to identify which patient will benefit from neck dissection is 
considered an indication by National Comprehensive Cancer Network and Society of Nuclear Medicine guidelines $[40,41]$. However, some data suggested no added value of PET compared with conventional imaging in this purpose, but these data were acquired on a PET-alone camera (not PET-CT) and performed as early as 7-weeks after completion of treatment [45]. Residual inflammation is known to increase the rate of false-positive uptake in these delays. Ongoing studies such as PET-NECK and GETTEC (Groupe d'Etude des Tumeurs de la Tete et du Cou) studies should further clarify the precise role of PET-CT in this indication.

Intense research is ongoing in radiation oncology to evaluate the role of molecular imaging for target volume delineation. In particular, FDG (glucose uptake) or other tracers such as $\left[{ }^{18} \mathrm{~F}\right]$-fluorothymidine (FLT, proliferation tracer) and $\left[{ }^{18} \mathrm{~F}\right]$-fluoroazomycinarabinoside (FAZA, hypoxia tracer) are currently studied for their potential ability to identify subzones of the tumor with more hypoxia (FAZA) or tumor proliferation (FLT) $[46,47]$. This information could lead radiation oncologists to target small areas of the tumor with higher radiation doses ('dose painting') to reach better local control [48].

\subsection{Computed tomography and magnetic resonance Tumor imaging}

Both CT scanner and magnetic resonance imaging (MRI) are giving highly relevant information about location, size, shape, and contours of the primary tumor [49]. The two modalities have specific advantages but also suffer from significant limitations: 'fast' CT is able to freeze motion artefacts and has the unsurpassed advantage in yielding information about electron density, useful for RT planning. 'Slow' MRI has the major advantage of enhancing soft tissue contrast, including the bone marrow, whereas CT detects the mineralized tissues. Main limitations of both modalities are the overestimation of the gross tumor volume by $30 \%$ to $60 \%$ when compared with FDG-PET because of their inability to separate the tumor from the adjacent reactive changes [50].

\section{Nodal imaging}

Morphological CT or MRI images have insufficient diagnostic accuracy because nodal size is not a robust predictor of the presence of metastases. CT and MRI perform similarly in nodal staging. Enlarged nodes can be benign (inflammatory changes), and small-sized nodes can host micro-metastases. When a cutoff value at $10 \mathrm{~mm}$ (short axis diameter) is used, an overall diagnostic accuracy of only $80 \%$ is achieved by both modalities [51]. Twenty-five percent of clinically and radiologically NO necks are positive at histopathology. Other criteria such as heterogeneity (central necrosis), round shape, differential enhancement, irregular margins (suggesting extra-nodal spreading), and clustering of more than three nodes are being considered as ancillary criteria for malignancy but require validation [52].

Distant metastases imaging

Newly available multi-row CT systems are used for metastatic work-up. Emerging 'whole-body' MRI techniques combining morphological imaging and diffusionweighted imaging (DWI) hold major promise in the field [53].

\subsection{Diffusion- and perfusion-weighted imaging}

DWI gives a quantitative index of the free-water diffusion restriction as encountered in tissues with high cellular density. For tumor imaging, the DWI technique allows tumor characterization at initial work-up (benign versus malignant), pre-treatment prognosis, early treatment response evaluation, and recurrence detection [54]. For nodal imaging, DWI seems extremely useful to differentiate tumoral and non-tumoral nodes but with the limitation that the DWI technique is uneasy to standardize and requires expertise in pulse sequence programming, image processing, and quantitative data interpretation [55].

Perfusion-weighted imaging (PWI) has shown the ability to predict patient outcome [56]. Multiparametric approaches combining PET metabolic information and MRI 'functional' DWI or PWI data (or both) are currently being investigated $[57,58]$.

\section{Challenges and perspectives in (chemo) radiation}

The head and neck region contains numerous intricately organized organs essential for basic physiological functions and critical for physical appearance, expression, and social interactions. Therefore, minimizing radiationrelated toxicities is the main challenge.

Technological innovations have greatly changed the way the dose is delivered. The use of three-dimensional treatment planning and the ability to modulate the beams during treatment allowed a more accurate dose delivery with steeper dose gradients around the target volume, allowing a decrease of the dose to the surrounding organs at risk while maintaining target coverage (Figure 2) [59]. This so-called intensity-modulated radiotherapy (IMRT) was rapidly implemented in SCCHN as it allowed a significant sparing of the contralateral parotid, effectively reducing the rate of severe late xerostomia in these patients without compromising outcome [60-62]. The role of IMRT in reducing other toxicities such as late dysphagia is 
Figure 2. The potential of intensity-modulated radiotherapy (IMRT)

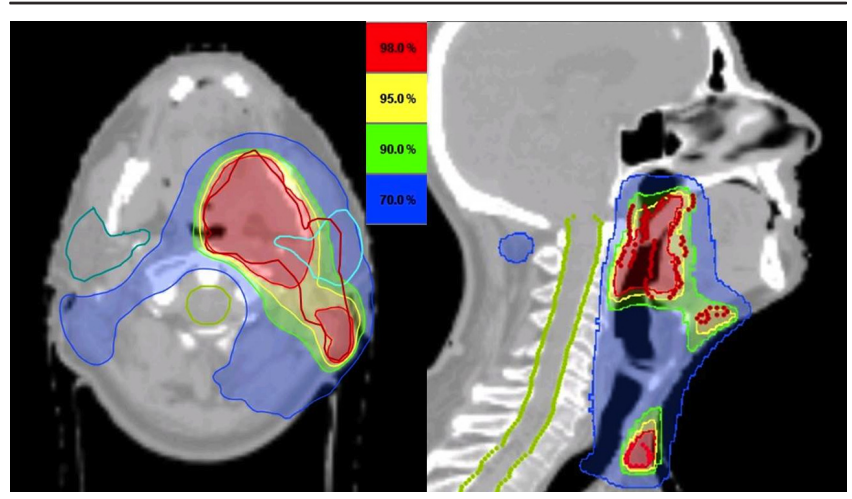

A squamous cell carcinoma of the left tonsil from a 58-year-old patient was classified as cT4aN2c. IMRT allows steep dose gradients to be generated, ensuring an adequate target coverage while sparing surrounding at-risk organs such as the contralateral parotid gland (dark green) and the spinal cord (light green).

currently being investigated [63-65]. On the other hand, the effect of IMRT on tumor control is much debated. As poorly implemented, it harbors an increased risk of missing the target volume [66,67]. Internationally endorsed delineation guidelines are of paramount importance to reduce inter-observer and inter-patient treatment variations and have proven essential in the conduction of multi-institutional clinical trials [68-70]. A recent analysis of the Surveillance, Epidemiology, and End Results (SEER) database demonstrated that the use of IMRT was associated with a significant improvement in cause-specific survival compared with non-IMRT techniques [71]. There is growing interest in using IMRT in strategies to increase tumor control by escalating the dose to the target volume. For example, the information provided by imaging techniques such as FDG-PET and functional MRI could improve target volume delineation and might even identify regions of increased radioresistance within the tumor $[50,72,73]$. Therefore, we have both the rationale and the means to target these subvolumes selectively with a higher radiation dose without increasing the doses to the surrounding organs at risk. Theoretically, such a so-called 'dosepainting' approach could increase tumor control while maintaining the same toxicity levels. Other approaches have already been investigated. In an attempt to exploit the differential sensitivity between tumor cells and normal tissue, the idea arose to deviate from conventional fractionation schedules [74]. In a large metaanalysis, Bourhis et al. found that altered fractionation schedules improve survival compared with conventional fractionation [75].
The combination of RT with chemotherapy and other radiosensitizers has been investigated. The updated metaanalysis of chemotherapy in combination with radiation for SCCHN (Meta-Analyses of Chemotherapy in Head and Neck Cancer, or MACH-NC) showed that the addition of chemotherapy concomitantly to radiation improves the absolute 5 -year survival by $6.5 \%[76,77]$. Concomitant platinum-based CRT is the standard of care in locally advanced SCCHN.

The exact role of induction chemotherapy with docetaxel, cisplatin, and 5-fluorouracil (TPF) remains controversial and investigational. So far, several randomized trials testing sequential approaches with TPF induction followed by concurrent CRT versus concurrent CRT alone have been reported [78-80]. They failed to demonstrate a statistically significant difference in OS and PFS. Cetuximab combined with RT improves locoregional control and OS rate compared with RT alone, apparently without increasing the radiation-induced side effects [81]. Cetuximab-RT is therefore considered an alternative to CRT; however, so far there are no data comparing CRT with cetuximab-RT.

In an attempt to improve outcome, several studies have attempted to combine the above-mentioned treatment strategies. In both the RTOG (Radiation Therapy Oncology Group) 0129 and the GORTEC (Groupe Oncologie Radiothérapie Tête et Cou) 99-02 trials, accelerated CRT failed to demonstrate a benefit compared with conventionally fractionated CRT $[2,82]$. Both trials concluded that acceleration seemed unable to compensate for the absence of concurrent chemotherapy. Similarly, the combination of EGFR targeting drugs with CRT has failed to demonstrate any benefit so far $[83,84]$.

\section{Challenges and perspectives in surgery}

In the past, advanced resectable tumors were preferentially treated by primary radical surgery followed by adjuvant RT. During the nineties, the development of CRT dramatically changed the role of surgery for locally advanced SCCHN, in particular when a voice-sparing surgical approach was not possible [85-87]. Today, primary total pharyngolaryngectomy remains indicated only in very advanced resectable cancer, when the ability to recover a functional organ after CRT is low. Open surgery remains the best primary treatment for a majority of head and neck tumors localized in the oral cavity, salivary glands, thyroid gland, nose and paranasal sinus, skull base, and skin as well as for sarcomas of the head and neck [88].

The concept of minimally invasive surgery includes laser and robotic surgery. For small transorally accessible 
cancers of the oral cavity, pharynx, and larynx, surgical excision can be achieved with functional preservation of the involved organ and good oncological results. Transoral laser surgery is less invasive compared with many open procedures. However, oncologic and functional outcomes of early glottic cancers do not seem better with laser surgery than with radiation, despite the lack of prospective randomized trials [89,90]. For locally advanced laryngeal cancer, good long-term oncological outcome with laser microsurgery was recently reported [91,92]. Regarding oropharynx, minimally invasive approaches, including transoral laser microsurgery and recently robotic surgery, have shown improved functional outcomes and oncologic outcomes similar to primary radiation [93]. There is little doubt that transoral robotic surgery, in experienced hands, is associated with less morbidity than traditional open surgery. Resection is possible without a mandibulotomy approach. However, we should be prudent about assuming that something must be better just because it is newer: in one series, suboptimal exposure was reported in $26 \%$ and postoperative hemorrhages in $12 \%$, leading to death in $2 \%$ [94]. Currently indicated for early oropharyngeal carcinoma, this approach has been employed in the management of supraglottic cancer. However, with the exception of base of tongue tumors, many T1-T2 oropharynx cancers can be resected transorally. Importantly, regardless of the surgical approach, elective neck dissection is recommended in patients clinically NO because the risk of occult lymph node metastases is around 30\% [95]. Typically, unilateral or bilateral dissection of levels II, III, and IV is indicated in oropharynx cancer. Robust data from a randomized trial comparing oncologic and functional outcomes of transoral surgery plus elective neck dissection versus RT including the tumor site and the lymph nodes at risk in the clinical target volume are lacking.

Regarding advanced head and neck squamous cell carcinoma, the emergence of organ preservation strategies has considerably limited the role of primary surgery in this setting. The surgeon is more frequently faced with failures of primary non-surgical therapies. Besides the expertise of the surgeon, an accurate selection of the patients who are suitable for surgery and who require a combination of large resection and well-vascularized flap reconstruction is key in salvage surgery. Although the definition of unresectability is not uniform, it is typically accepted that a tumor invading the common carotid artery, the base of the skull, or the prevertebral muscles should be considered unresectable. Advances in microrevascularized free flaps have considerably expanded the possibilities of reconstruction following resection of advanced tumors. Accurate tailoring of the flap improves the cosmetic result and the functional outcome (Figure 3). Use of these flaps has allowed voice-preservation surgery for selected patients with advanced hypopharyngeal or laryngeal cancer, even after failure of organ-sparing therapy [96].

When surgery is the primary treatment, neck dissection is recommended in most tumors with the exception of early tumors of the vocal cord. The rationale for a selective neck dissection is based on known patterns of metastases from each site. Currently, selective neck dissection is an oncologically safe and low-morbidity surgical procedure indicated for clinically negative necks harboring a risk of micrometastasis in up to $30 \%$ and for clinically N1 disease $[97,98]$. In patients treated with primary CRT, neck dissection is recommended when residual disease is suspected, whereas its role remains controversial in the setting of complete response $[99,100]$. However, because patients achieving a complete clinical response to CRT have a very low risk of an isolated neck recurrence, the strategy of systematic neck dissection is no longer justified [101]. The next issues are to identify patients who have residual anatomic abnormalities with no viable tumor cells and to improve the outcome of patients who have pathological residual disease. Use of less morbid neck dissection after CRT was progressively proposed in patients initially staged N2-N3 with a very low rate of subsequent neck failure [102,103].

Figure 3. Oropharyngectomy through mandibular swing approach

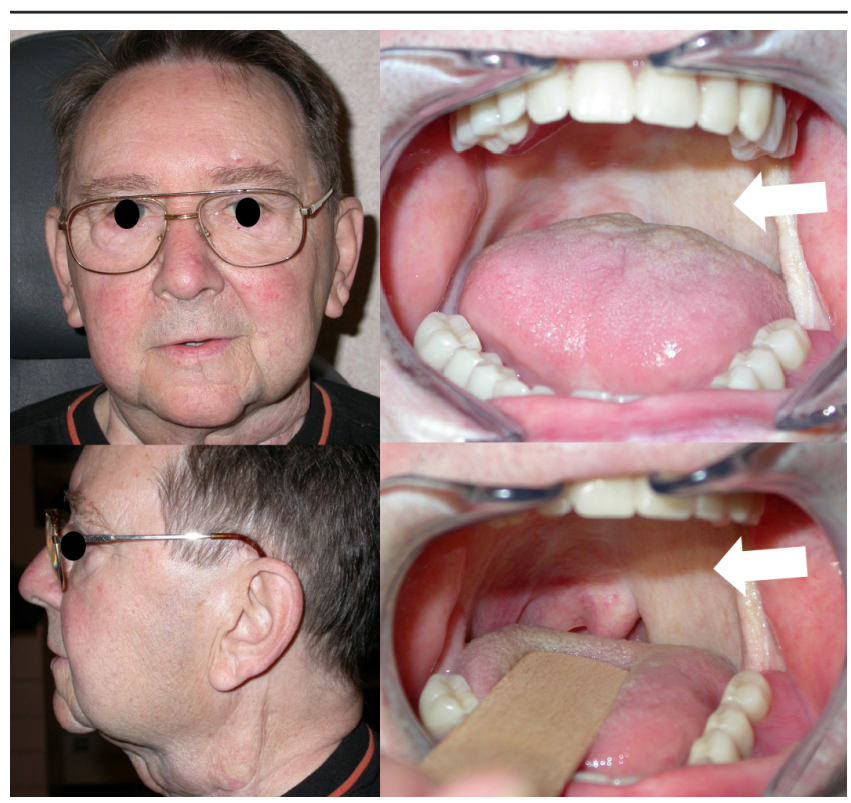

Reconstruction of the soft palate and lateral oropharynx with a microrevascularized radial forearm free flap (arrows) is shown. 
Many publications support the suitability of selective neck dissection after chemoradiation in patients with initially advanced regional disease and in patients with clinically persistent disease [98,104-106].

\section{Recurrent or metastatic disease or both}

SCCHN that recurs after multimodal local treatment is generally considered incurable if the patient cannot be salvaged by surgery or additional RT. Platinum-based chemotherapy in combination with cetuximab is considered the standard of care in fit patients. The combination of cisplatin or carboplatin with 5-fluorouracil and cetuximab improves OS (median OS is 10.1 months) [18]. Docetaxel, paclitaxel, and methotrexate are other chemotherapy compounds sometimes used in this indication. Based on the improvement in SCCHN molecular biology knowledge, new compounds are currently being investigated (EGFR/HER-3 dual, irreversible pan-HER or PI3K inhibitors, cell cycle inhibitors) [107].

\section{Conclusions}

SCCHN is a heterogeneous disease at both the anatomical and molecular levels. An experienced multidisciplinary team is necessary for adequate management and to optimize the outcome. Despite multimodal treatment, including surgery, RT, chemotherapy, or some combination thereof, $40 \%$ to $60 \%$ of the patients with locally advanced SCCHN will relapse. Further treatment intensification with these classic treatment modalities is almost impossible since the maximal tolerable toxicity is reached, limiting further improvement in treatment.

Improvement in technology, including imaging, radiation technique, and surgery, has allowed better functional and cancer outcomes. Ongoing trials address important questions regarding treatment sequences (i.e., induction versus concomitant CRT, de-escalation in $\mathrm{HPV}^{+}$cancer, induction followed by cetuximab-RT). In addition, our better understanding of the molecular biology of the disease has opened new treatment avenues that should be explored in the near future with the hope that targeted therapies may help to circumvent the toxicities of the classic modalities. However, only a minority of patients seem to benefit from molecular targeted therapies. Therefore, a major challenge in coming years will be to identify predictive biomarkers to tailor each treatment to the most appropriate population.

\section{Abbreviations}

AJCC, American Joint Committee on Cancer; CRT, chemoradiotherapy; CT, computerized tomography; DWI, diffusion-weighted imaging; EGFR, epidermal growth factor receptor; FAZA, $\left[{ }^{18} \mathrm{~F}\right]$-fluoroazomycin- arabinoside; FDG, ${ }^{18} \mathrm{~F}$-fluorodeoxyglucose; FLT, $\left[{ }^{18} \mathrm{~F}\right]-$ fluorothymidine; HPV, human papillomavirus; IMRT, intensity-modulated radiotherapy; MRI, magnetic resonance imaging; OS, overall survival; PI3K (phosphoinositide 3-kinase); PET, positron emission tomography; PFS, progression-free survival; PWI, perfusion-weighted imaging; RT, radiotherapy; SCCHN, squamous cell carcinoma of the head and neck; TPF, docetaxel, cisplatin, and 5-fluorouracil.

\section{Disclosures}

The authors declare that they have no disclosures.

\section{References}

I. International Agency for Research on Cancer. World Health Organisation. Globocan 2012: Estimated cancer incidence, mortality and prevalence worldwide in 20I2. [http://globoscan.iarc.fr]

2. Ang KK, Harris J, Wheeler R, Weber R, Rosenthal DI, Nguyen-Tân PF, Westra WH, Chung CH, Jordan RC, Lu C, Kim H, Axelrod R, Silverman CC, Redmond KP, Gillison ML: Human papillomavirus and survival of patients with oropharyngeal cancer. $N$ Eng J Med 2010, 363:24-35.

FlOOOPrime

RECOMMENDED

3. Gillison ML: Human papillomavirus-associated head and neck cancer is a distinct epidemiologic, clinical, and molecular entity. Semin Oncol 2004, 31:744-54.

4. Chaturvedi AK, Anderson WF, Lortet-Tieulent J, Curado MP, Ferlay J, Franceschi S, Rosenberg PS, Bray F, Gillison ML: Worldwide trends in incidence rates for oral cavity and oropharyngeal cancers. J Clin Oncol 2013, 31:4550-9.

5. Chaturvedi AK, Engels EA, Pfeiffer RM, Hernandez BY, Xiao W, Kim E, Jiang B, Goodman MT, Sibug-Saber M, Cozen W, Liu L, Lynch CF, Wentzensen N, Jordan RC, Altekruse S, Anderson WF, Rosenberg PS, Gillison ML: Human papillomavirus and rising oropharyngeal cancer incidence in the United States. J Clin Oncol 2011, 29:4294-301.

FlOOOPrime
RECOMMENDED

6. Ribeiro KB, Levi JE, Pawlita M, Koifman S, Matos E, Eluf-Neto J, Wunsch-Filho V, Curado MP, Shangina O, Zaridze D, SzeszeniaDabrowska N, Lissowska J, Daudt A, Menezes A, Bencko V, Mates D, Fernandez L, Fabianova E, Gheit T, Tommasino M, Boffetta P, Brennan $\mathrm{P}$, Waterboer $\mathrm{T}$ : Low human papillomavirus prevalence in head and neck cancer: results from two large case-control studies in high-incidence regions. Int J Epidemiol 201 I, 40:489-502.

7. Grégoire V, Lefebvre J-L, Licitra L, Felip E: Squamous cell carcinoma of the head and neck: EHNS-ESMO-ESTRO Clinical practice guidelines for diagnosis, treatment and follow-up. Ann Oncol 2010, 21 :v184-6.

FlOOOPrime RECOMMENDED

8. Kalyankrishna S, Grandis JR: Epidermal growth factor biology in head and neck cancer. J Clin Oncol 2006, 24:2666-72.

9. Temam S, Kawaguchi H, El-Naggar AK, Jelinek J, Tang H, Liu DD, Lang W, Issa JP, Lee JJ, Mao L: Epidermal growth factor receptor copy number alterations correlate with poor clinical outcome in patients with head and neck squamous cancer. J Clin Oncol 2007, 25:2164-70.

10. Mrhalova M, Plzak J, Betka J, Kodet R: Epidermal growth factor receptor-its expression and copy numbers of EGFR gene in patients with head and neck squamous cell carcinoma. Neoplasma 2005, 52:338-43.

II. Chung CH, Ely K, McGavran L, Varella-Garcia M, Parker J, Parker N, Jarrett C, Carter J, Murphy BA, Netterville J, Burkey BB, Sinard R, Cmelak A, Levy S, Yarbrough WG, Slebos RJ, Hirsch FR: Increased 
epidermal growth factor receptor gene copy number is associated with poor progonis in head and neck squamous cell carcinomas. J Clin Oncol 2006, 24:4I70-76.

12. Chiang WF, Liu SY, Yen CY, Lin CN, Chen YC, Lin SC, Chang KW: Association of epidermal growth factor receptor (EGFR) gene copy number amplification with neck lymph node metastasis in areca-associated oral carcinoma. Oral Oncol 2008, 44:270-6.

13. Ang KK, Berkey BA, Tu X, Zhang HZ, Katz R, Hammond EH, Fu KK, Milas $L$ : Impact of epidermal growth factor receptor expression on survival and pattern of relapse in patients with advanced head and neck carcinoma. Cancer Res 2002, 62:7350-56.

14. Wheeler S, Siwak DR, Chai R, LaValle C, Seethala RR, Wang L, Cieply K, Sherer C, Joy C, Mills GB, Argiris A, Siegfried JM, Grandis JR, Egloff AM: Tumor epidermal growth factor receptor and EGFR PYI068 are independent prognostic indicators for head and neck squamous cell carcinoma. Clin Cancer Research 20I2, 18:2278-89.

15. Rubin Grandis JR, Melhem MF, Gooding WE, Day R, Holst VA, Wagener MM, Drenning SD, Tweardy DJ: Levels of TGFA and EGFR protein in head and neck squamous cell carcinoma and patient survival. J Natl Cancer Inst 1998, 90:824-32.

16. Jedlinski A, Ansell A, Johansson AC, Roberg KJ: EGFR status and EGFR ligand expression influence the treatment response of head and neck cancer cell lines. Oral Pathol Med 2013, 42:26-36.

17. Bentzen SM, Atasoy BM, Daley FM, Dische S, Richman PI, Saunders MI, Trott KR, Wilson GD: Epidermal growth factor receptor expression in pretreatment biopsies from head and neck squamous cell carcinoma as a predictive factor for a benefit from accelerated radiation therapy in a randomized controlled trial. J Clin Oncol 2005, 23:5560-67.

18. Vermorken J, Mesia R, Rivera F, Remenar E, Kawecki A, Rottey S, Erfan J, Zabolotnyy D, Kienzer HR, Cupissol D, Peyrade F, Benasso M, Vynnychenko I, De Raucourt D, Bokemeyer C, Schueler A, Amellal N, Hitt R: Platinum-based chemotherapy plus cetuximab in head and neck cancer. N Eng J Med 2008, II:III 6-27.

\section{FlOOOPrime
RECOMMENDED}

19. Bonner JA, Harari PM, Giralt J, Cohen RB, Jones CU, Sur RK, Raben D, Baselga J, Spencer SA, Zhu J, Youssoufian H, Rowinsky EK, Ang KK: Radiotherapy plus cetuximab for locoregionally advanced head and neck cancer: 5-year survival data from a phase 3 randomised trial, and relation between cetuximabinduced rash and survival. Lancet Oncol 2010, II:2I-8.

\section{FlOOOPrime} RECOMMENDED

20. Machiels JP, Subramanian S, Ruzsa A, Repassy G, Lifirenko I, Flygare A, Sørensen $P$, Nielsen T, Lisby L, Clement $P$ : Zalutumumab in patients with squamous cell carcinoma of the head and neck with recurrent or metastatic disease who failed platinum based chemotherapy, a randomized controlled trial. Lancet Oncol 2011, 12:333-343.

21. Vermorken JB, Herbst RS, Leon X, Amellal N, Baselga J: Overview of the efficacy of cetuximab in recurrent and/or metastatic squamous cell carcinoma of the head and neck in patients who previously failed platinum-based therapies. Cancer 2008, I | 2:27| 0-9.

22. Stransky N, Egloff AM, Tward AD, Kostic AD, Cibulskis K, Sivachenko A, Kryukov GV, Lawrence MS, Sougnez C, McKenna A, Shefler E, Ramos AH, Stojanov P, Carter SL, Voet D, Cortés ML, Auclair D, Berger MF, Saksena G, Guiducci C, Onofrio RC, Parkin M, Romkes M, Weissfeld JL, Seethala RR, Wang L, Rangel-Escareño C, Fernandez-Lopez JC, Hidalgo-Miranda A, Melendez-Zajgla J, et al.: The mutational landscape of head and neck squamous cell carcinoma. Science 20II, 333: I I57-60.

\section{FlOOOPrime RECOMMENDED}

23. Agrawal N Frederick MJ, Pickering CR, Bettegowda C, Chang K, Li RJ, Fakhry C, Xie TX, Zhang J, Wang J, Zhang N, El-Naggar AK, Jasser SA,
Weinstein JN, Treviño L, Drummond JA, Muzny DM, Wu Y, Wood LD, Hruban RH, Westra WH, Koch WM, Califano JA, Gibbs RA, Sidransky D, Vogelstein B, Velculescu VE, Papadopoulos N, Wheeler DA, Kinzler KW, et al.: Exome sequencing of head and neck squamous cell carcinoma reveals inactivating mutations in NOTCHI. Science 201 I, 333:1 154-57.

\section{FlOOOPrime
RECOMMENDED}

24. Hayes DN, Grandis JR, El-Naggar AK: The Cancer Genome Atlas: Integrated analysis of genome alterations in squamous cell carcinoma of the head and neck [abstract]. J Clin Oncol 2013, $31: s 6009$.

25. Perez-Sayans M, Suarez-Penaranda JM, Gayoso-Diz P, BarrosAngueira F, Gandara-Rey JM, Garcia-Garcia A: pI6(INK4a)/ CDKN2 expression and its relationship with oral squamous cell carcinoma is our current knowledge enough? Cancer Lett 2009, 306: $134-4 \mid$.

26. Reed AL, Califano J, Cairns P, Westra WH, Jones RM, Koch W, Ahrendt S, Eby Y, Sewell D, Nawroz H, Bartek J, Sidransky D: High frequency of pl6 (CDKN2/MTS-I/INK4A) inactivation in head and neck squamous cell carcinoma. Cancer Res 1996, 56:3630-33.

27. Smeets SJ, Brakenhoff RH, Ylstra $B$, van Wieringen $W N$, van de Wiel MA, Leemans CR, Braakhuis BJ: Genetic classification of oral and oropharyngeal carcinomas identifies subgroups with a different prognosis. Cell Oncol 2009, 31:291-300.

28. Smeets SJ, Braakhuis BJ, Abbas S, Snijders PJ, Ylstra B, van de Wiel MA, Meijer GA, Leemans CR, Brakenhoff RH: Genome-wide DNA copy number alterations in head and neck squamous cell carcinomas with or without oncogene-expressing human papillomavirus. Oncogene 2006, 25:2558-64.

29. Bova RJ, Quinn DI, Nankervis JS, Cole IE, Sheridan BF, Jensen MJ, Morgan G], Hughes CJ, Sutherland RL: Cyclin DI and pI6INK4A expression predict reduced survival in carcinoma of the anterior tongue. Clin Cancer Res 1999, 5:2810-19.

30. Narisawa-Saito M, Kiyono T: Basic mechanisms of high risk human papillomavirus -induced carcinogenesis: Roles of E6 and E7 proteins. Cancer Sci 2007, 98:I505-II.

3I. Slebos RJ, Yi Y, Ely K, Carter J, Evjen A, Zhang X, Shyr Y, Murphy BM, Cmelak AJ, Burkey BB, Netterville JL, Levy S, Yarbrough WG, Chung $\mathrm{CH}$ : Gene expression differences associated with human papillomavirus status in head and neck squamous cell carcinoma. Clin Cancer Res 2006, I 2:70I-9.

32. Nichols AC, Chan-Seng-Yue M, Yoo J, Xu W, Dhaliwal S, Basmaji J, Szeto CC, Dowthwaite S, Todorovic B, Starmans MH, Lambin P, Palma DA, Fung K, Franklin JH, Wehrli B, Kwan K, Koropatnick J, Mymryk JS, Boutros P, Barrett JW: A pilot study comparing HPVpositive and HPV-negative head and neck squamous cell carcinomas by whole exome sequencing. ISRN Oncol 2012, 201 2:809370.

\section{FloOOPrime \\ RECOMMENDED}

33. Lechner M, Frampton GM, Fenton T, Feber A, Palmer G, Jay A, Pillay N, Forster M, Cronin MT, Lipson D, Miller VA, Brennan TA, Henderson S, Vaz F, O'Flynn P, Kalavrezos N, Yelensky R, Beck S, Stephens PJ, Boshoff C: Targeted next-generation sequencing of head and neck squamous cell carcinoma identifies novel genetic alterations in HPV+ and HPV- tumors. Genome Med 2013, 5:49.

\section{FIOOOPrime}

34. Weinberger PM, Yu Z, Kountourakis P, Sasaki C, Haffty BG, Kowalski D, Merkley MA, Rimm DL, Camp RL, Psyrri A: Defining molecular phenotypes of human papillomavirus-associated oropharyngeal squamous cell carcinoma: validation of threeclass hypothesis. Otolaryngol Head Neck Surg 2009, I41:382-9.

35. Smith EM, Rubenstein LM, Hoffman H, Haugen TH, Turek LP: Human papillomavirus, pl6 and p53 expression associated with survival of head and neck cancer. Infect Agent Cancer 2010, 5:4. 
36. Gillison ML, Harris J, Westra W, Chung C, Jordan R, Rosenthal D, Nguyen-Tan P, Spanos WJ, Redmond KP, Ang K and Radiation Therapy Oncology Group: Survival outcomes by tumor human papillomavirus (HPV) status in stage III-IV oropharyngeal cancer (OPC) in RTOG 0129 [abstract]. J Clin Oncol 2009, 27:s6003.

37. Schoder H, Yeung HW, Gonen M, Kraus D, Larson SM: Head and neck cancer: clinical usefulness and accuracy of PET/CT image fusion. Radiology 2004, 231 :65-72.

38. Wong WL, Ross P, Corcoran M: Evidence-based guideline recommendations on the use of positron emission tomography imaging in head and neck cancer from Ontario and guidelines in general-some observations. Clin Oncol ( $R$ Coll Radiol) 2013, 25:242-5.

39. Wong WL, Sonoda LI, Gharpurhy A, Gollub F, Wellsted D, Goodchild K, Lemon C, Farrell R, Saunders M: I8F-fluorodeoxyglucose positron emission tomography/computed tomography in the assessment of occult primary head and neck cancers-an audit and review of published studies. Clin Oncol ( $R$ Coll Radiol) 2012, 24:190-5.

FlOOOPrime RECOMMENDED

40. NCCN: National Comprehensive Cancer Network Clinical Practice guidelines in Oncology: Head and Neck cancers. Version 2.20I3; 20I4. [http://oralcancerfoundation.org/treatment/pdf/ head-and-neck.pdf]

41. SNM: Society of Nuclear Medicine Oncology practice Guidelines Summary; 20I3. [http://www.snm.org/docs/PET_PROS/ OncologyPracticeGuidelineSummary.pdf]

42. Escott E): Role of positron emission tomography/computed tomography (PET/CT) in head and neck cancer. Radiol Clin North Am 2013, 5 I:881-93.

43. Gupta T, Master Z, Kannan S, Agarwal JP, Ghsoh-Laskar S, Rangarajan $\mathrm{V}$, Murthy $\mathrm{V}$, Budrukkar A: Diagnostic performance of post-treatment FDG PET or FDG PET/CT imaging in head and neck cancer: a systematic review and meta-analysis. Eur J Nucl Med Mol Imaging 20II, 38:2083-95.

\section{FlOOOPYime
RECOMMENDED}

44. Porceddu SV, Pryor DI, Burmeister E, Burmeister BH, Poulsen MG, Foote MC, Panizza B, Coman S, McFarlane D, Coman W: Results of a prospective study of positron emission tomographydirected management of residual nodal abnormalities in node-positive head and neck cancer after definitive radiotherapy with or without systemic therapy. Head Neck 201I, 33:1675-82.

\section{FIOOOPrime}

45. Inohara $\mathrm{H}$, Enomoto $\mathrm{K}$, Tomiyama $\mathrm{Y}$, Higuchi I, Inoue $\mathrm{T}$, Hatazawa J: The role of CT and (I)(8)F-FDG PET in managing the neck in node-positive head and neck cancer after chemoradiotherapy. Acta Otolaryngol 2009, I 29:893-9.

46. Grosu AL, Souvatzoglou M, Roper B, Dobritz M, Wiedenmann N, Jacob V, Wester HJ, Reischl G, Machulla HJ, Schwaiger M, Molls M, Piert M: Hypoxia imaging with FAZA-PET and theoretical considerations with regard to dose painting for individualization of radiotherapy in patients with head and neck cancer. Int J Radiat Oncol Biol Phys 2007, 69:54I-5I.

47. Lelandais B, Gardin I, Mouchard L, Vera P, Ruan S: Segmentation of biological target volumes on multi-tracer PET images based on information fusion for achieving dose painting in radiotherapy. Med Image Comput Comput Assist Interv 2012, 15:545-52.

48. Gregoire V, Jeraj R, Lee JA, O'Sullivan B: Radiotherapy for head and neck tumours in 2012 and beyond: conformal, tailored, and adaptive? Lancet Oncol 2012, 13:e292-300.

49. Petrou M, Mukherji SK: Extracranial head and neck neoplasm: role of imaging. Cancer Treat Res 2008, I 43:93-II7.

50. Daisne JF, Duprez T, Weynand B, Lonneux M, Hamoir M, Reychler H, Grégoire $V$ : Tumor volume in pharyngolaryngeal squamous cell carcinoma: comparison at CT, MR imaging, and FDG
PET and validation with surgical specimen. Radiology 2004 233:93-100.

5I. Curtin HD, Ishwaran H, Dalley RW, Caudry DJ, McNeil BJ: Comparison of CT and MR imaging in staging of neck metastases. Radiology 1998, 207:123-30.

52. King $A D$, Tse GM, Ahuja AT, Yuen EH, Vlantis A, To EW, van Hasselt AC: Necrosis in metastatic neck nodes: diagnostic accuracy of CT, MR imaging, and US. Radiology 2004, 230:720-26.

53. Schmidt GP, Kramer H, Reiser MF, Glaser C: Whole-body magnetic resonance imaging and positron emission tomography-computed tomography in oncology. Top Magn reson Imaging 2007, I 8:193-202.

\section{FIOOOPRime}

54. Thoeny HC, De Keyzer F, King AD: Diffusion-weighted MR imaging in the head and the neck. Radiology 2012, 263:19-32.

55. Vandecaveye V, De Keyzer F, Vander Poorten V, dirix P, Verbeken E, Nuyts $S$, Hermans R: Head and neck squamous cell carcinoma: value of diffusion-weighted MR imaging for nodal staging. Radiology 2009, 25 I: | 34-45.

\section{FlOOOPrime
RECOMMENDED}

56. Shukla-Dave A, Lee NY, Jansen JFA, Thaler HT, Stambuk HE, Fury MG, Patel SG, Moreira AL, Sherman E, Karimi S, Wang Y, Kraus D, Shah JP, Pfister DG, Koutcher JA: Dynamic contrast-enhanced MRI as predictor of outcome in HNSCC patients with nodal metastases. Int J Radiation Oncology Biol Phys 2012, 82:1837-44.

57. Varoquaux A, Rager O, Lövblad K-O, Masterson K, Dulguerov $P$, Ratib O, Becker CD, Becker M: Functional imaging of HNSCC with diffusion-weighted MRI and FDG PET/CT: quantitative analysis of ADC and SUV. Eur J Nucl Med Mol Imaging 2014, $41: 462-75$.

58. Sumi M, Nakamura T: Head and neck tumors: combined MRI assessment based on IVIM and TIC analyses for the differentiation of tumors of different histological types. Eur Radiol 2014, 24:223-3I.

59. Veldeman L, Madani I, Hulstaert F, De Meerleer G, Mareel M, De Neve W: Evidence behind use of intensity-modulated radiotherapy: a systematic review of comparative clinical studies. Lancet Oncol 2008, 9:367-75.

\section{FlOOOPrime \\ RECOMMENDED}

60. Nutting CM, Morden JP, Harrington KJ, Urbano TG, Bhide SA, Clark C, Miles EA, Miah AB, Newbold K, Tanay M, Adab F, Jefferies SJ, Scrase C, Yap BK, A'Hern RP, Sydenham MA, Emson M, Hall E; PARSPORT trial management group: Parotid-sparing intensity modulated versus conventional radiotherapy in head and neck cancer (PARSPORT): a phase 3 multicentre randomised controlled trial. Lancet Oncol 20II, I2:127-36.

\section{FlOOOPrime \\ RECOMMENDED}

6I. Kam MK, Leung SF, Zee B, Chau RM, Suen JJ, Mo F, Lai M, Ho R, Cheung KY, Yu BK, Chiu SK, Choi PH, Teo PM, Kwan WH, Chan AT: Prospective randomized study of intensity-modulated radiotherapy on salivary gland function in early-stage nasopharyngeal carcinoma patients. J Clin Oncol 2007, 25:4873-9.

\section{FlOOOPrime}

\section{RECOMMENDED}

62. Pow EH, Kwong DL, McMillan AS, Wong MC, Sham JS, Leung LH, Leung WK: Xerostomia and quality of life after intensitymodulated radiotherapy vs. conventional radiotherapy for early-stage nasopharyngeal carcinoma: initial report on a randomized controlled clinical trial. Int J Radiat Oncol Biol Phys 2006, 66:98I-91.

63. Feng FY, Kim HM, Lyden TH, Haxer MJ, Feng M, Worden FP, Chepeha DB, Eisbruch A: Intensity-modulated radiotherapy of head and neck cancer aiming to reduce dysphagia: early 
dose-effect relationships for the swallowing structures. Int J Radiat Oncol Biol Phys 2007, 68: I289-98.

64. Eisbruch A, Kim HM, Feng FY, Lyden TH, Haxer MJ, Feng M, Worden FP, Bradford CR, Prince ME, Moyer JS, Wolf GT, Chepeha DB, Ten Haken RK: Chemo-IMRT of oropharyngeal cancer aiming to reduce dysphagia: swallowing organs late complication probabilities and dosimetric correlates. Int J Radiat Oncol Biol Phys 20II, 8I:e93-9.

65. Nuyts S, Lambrecht M, Duprez F, Daisne JF, Van Gestel D, Van den Weyngaert D, Platteaux N, Geussens Y, Voordeckers M, Madani I, De Neve W: Reduction of the dose to the elective neck in head and neck squamous cell carcinoma, a randomized clinical trial using intensity modulated radiotherapy (IMRT). Dosimetrical analysis and effect on acute toxicity. Radiother Oncol 2013, 109:323-9.

66. Mendenhall WM, Amdur RJ, Palta JR: Intensity-modulated radiotherapy in the standard management of head and neck cancer: promises and pitfalls. J Clin Oncol 2006, 24:2618-23.

67. Feng $M$ and Eisbruch $A$ : Future issues in highly conformal radiotherapy for head and neck cancer. J Clin Oncol 2007, 25:1009-13.

68. Chao KS, Wippold FJ, Ozyigit G, Tran BN, Dempsey JF: Determination and delineation of nodal target volumes for head-andneck cancer based on patterns of failure in patients receiving definitive and postoperative IMRT. Int J Radiat Oncol Biol Phys 2002, 53: I 174-84.

69. Eisbruch A, Foote RL, O'Sullivan B, Beitler JJ, Vikram B: Intensitymodulated radiation therapy for head and neck cancer: emphasis on the selection and delineation of the targets. Semin Radiat Oncol 2002, I 2:238-49.

70. Gregoire V, Ang K, Budach W, Grau C, Hamoir M, Langendijk JA, Lee A, Le QT, Maingon P, Nutting C, O'Sullivan B, Porceddu SV, Lengele $B$ : Delineation of the neck node levels for head and neck tumors: A 2013 update. DAHANCA, EORTC, HKNPCSG, NCIC CTG, NCRI, RTOG, TROG consensus guidelines. Radiother Oncol 2013, I 10:I72-8I.

7I. Beadle BM, Liao KP, Elting LS, Buchholz TA, Ang KK, Garden AS, Guadagnolo BA: Improved survival using intensity-modulated radiation therapy in head and neck cancers: A SEERMedicare analysis. Cancer 20 I4, I 20:702-10.

\section{FlOOOPrime}

\section{RECOMMENDED}

72. Bentzen SM and Gregoire V: Molecular imaging-based dose painting: a novel paradigm for radiation therapy prescription. Semin Radiat Oncol 2011, 21:101-10.

73. Lambrecht M, Van Herck H, de Keyzer F, Vandecaveye V, Slagmolen P, Suetens P, Hermans R, Nuyts S: Redefining the target early during treatment. Can we visualize regional differences within the target volume using sequential diffusion weighted MRI? Radiother Oncol 20I3, I I 0:329-34.

74. Withers HR: Biologic basis for altered fractionation schemes. Cancer 1985, 55:2086-95.

75. Bourhis J, Overgaard J, Audry H, Ang KK, Saunders M, Bernier J, Horiot JC, Le Maître A, Pajak TF, Poulsen MG, O'Sullivan B, Dobrowsky W, Hliniak A, Skladowski K, Hay JH, Pinto LH, Fallai C, Fu KK, Sylvester R, Pignon JP: Hyperfractionated or accelerated radiotherapy in head and neck cancer: a meta-analysis. Lancet 2006, 368:843-54.

\section{FlOOOPrime}

76. Pignon JP, le Maitre A, Maillard E, Bourhis: Meta-analysis of chemotherapy in head and neck cancer (MACH-NC): an update on 93 randomised trials and 17,346 patients. Radiother Oncol 2009, 92:4-14.

\section{FlOOOPrime}

\section{RECOMMENDED}

77. Blanchard P, Baujat B, Holostenco V, Bourredjem A, Baey C, Bourhis J, Pignon JP; MACH-CH Collaborative group: Metaanalysis of chemotherapy in head and neck cancer
(MACH-NC): a comprehensive analysis by tumour site. Radiother Oncol 201 I, I00:33-40.

\section{FlOOOPrime}

78. Hitt R, Grau JJ, López-Pousa A, Berrocal A, García-Girón C, Irigoyen A, Sastre J, Martínez-Trufero J, Brandariz Castelo JA, Verger E, CruzHernández Jj; Spanish Head and Neck Cancer Cooperative Group (TTCC): A randomized phase III trial comparing induction chemotherapy followed by chemoradiotherapy versus chemoradiotherapy alone as treatment of unresectable head and neck cancer. Ann Oncol 2014, 25:216-25.

\section{FlOOOPrime
RECOMMENDED}

79. Cohen EEW, Karrison T, Kocherginsky M, Huang $\mathrm{CH}$, Agulnik M, Mittal BB, Yunus F, Samant S, Brockstein B, Raez LE, Mehra R, Kumar P, Ondrey FG, Seiwert TY, Villaflor VM, Haraf DJ and Vokes EE: DeCIDE: a phase III randomized trial of docetaxel (D), cisplatin (P), 5-fluorouracil (F)(TPF) induction chemotherapy (IC) in patients with N2/N3 locally advanced squamous cell carcinoma of the head and neck (SCCHN) [abstract]. J Clin Oncol 2012, 30:s5500.

80. Haddad R, O'Neill A, Rabinowits G, Tishler R, Khuri F, Adkins D, Clark J, Sarlis N, Lorch J, Beitler JJ, Limaye S, Riley S, Posner M: Induction chemotherapy followed by concurrent chemoradiotherapy (sequential chemoradiotherapy) versus concurrent chemoradiotherapy alone in locally advanced head and neck cancer (PARADIGM): a randomised phase 3 trial. Lancet Oncol 2013, 14:257-64

81. Bonner JA, Harari PM, Giralt J, Azarnia N, Shin DM, Cohen RB, Jones CU, Sur R, Raben D, Jassem J, Ove R, Kies MS, Baselga J, Youssoufian H, Amellal N, Rowinsky EK, Ang KK: Radiotherapy plus cetuximab for squamous-cell carcinoma of the head and neck. N Engl J Med 2006, 354:567-78.

\section{FlOOOPrime} RECOMMENDED

82. Bourhis J, Sire C, Graff P, Grégoire V, Maingon P, Calais G, Gery B, Martin L, Alfonsi M, Desprez P, Pignon T, Bardet E, Rives M, Geoffrois L, Daly-Schveitzer N, Sen S, Tuchais C, Dupuis O, Guerif S, Lapeyre M, Favrel V, Hamoir M, Lusinchi A, Temam S, Pinna A, Tao YG, Blanchard P, Aupérin A: Concomitant chemoradiotherapy versus acceleration of radiotherapy with or without concomitant chemotherapy in locally advanced head and neck carcinoma (GORTEC 99-02): an open-label phase 3 randomised trial. Lancet Oncol 2012, I3:|45-53.

\section{FlOOOPrime
RECOMMENDED}

83. Ang KK, Zhang QE, Rosenthal DI, Nguyen-Tan P, Sherman EJ, Weber RS, Galvin JM, Schwartz DL, El-Naggar AK, Gillison ML, Jordan R, List MA, Konski AA, Thorstad WL, Trotti A, Beitler JJ, Garden AS, Spanos WJ, Yom SS and Axelrod RS: A randomized phase III trial (RTOG 0522) of concurrent accelerated radiation plus cisplain with our without cetuximab for stage III-IV head and neck squamous cell carcinoma. [abstract]. J Clin Oncol 2011, 29:s5500.

84. Martins RG, Parvathaneni $U$, Bauman JE, Sharma AK, Raez LE, Papagikos MA, Yunus F, Kurland BF, Eaton KD, Liao JJ, Mendez E, Futran N, Wang DX, Chai X, Wallace SG, Austin M, Schmidt R, Hayes DN: Cisplatin and radiotherapy with or without erlotinib in locally advanced squamous cell carcinoma of the head and neck: a randomized phase II trial. J Clin Oncol 20|3, 3|:|4|5-2|.

85. Ferlito A, Takes RP, Silver CE, Strojan P, Haigentz M Jr, Robbins KT, Genden EM, Hartl DM, Shaha AR, Rinaldo A, Suárez C, Olsen KD: The changing role of surgery in the current era of head and neck oncology. Eur Arch Otorhinolaryngol 2013, 270:1971-3.

86. The Department of Veterans Affairs Laryngeal Cancer Study Group: Induction Chemotherapy plus Radiation Compared with Surgery plus Radiation in Patients with Advanced Laryngeal Cancer. N Engl J Med I991, 324:1685-90. 
87. Forastiere AA, Goepfert H, Maor M, Pajak TF, Weber R, Morrison W, Glisson B, Trotti A, Ridge JA, Chao C, Peters G, Lee DJ, Leaf A, Ensley J, Cooper J: Concurrent chemotherapy and radiotherapy for organ preservation in advanced laryngeal cancer. $N$ Engl J Med 2003, 349:2091-8.

88. Hartl DM, Brasnu DF, Shah JP, Hinni ML, Takes RP, Olsen KD, Kowalski LP, Rodrigo JP, Strojan P, Wolf GT, Rinaldo A, Suárez C, Mendenhall WM, Paleri V, Forastiere AA, Werner JA, Ferlito A: Is open surgery for head and neck cancers truly declining? Eur Arch Otorhinolaryngol 2013, 270:2793-802.

\section{FlOOOPrime \\ RECOMMENDED}

89. Grégoire V, Hamoir M, Rosier JF, Counoy H, Eeckhoudt L, Neymark N, Scalliet P: Cost-minimization analysis of treatment options for TINO glottic squamous cell carcinoma: comparison between external radiotherapy, laser microsurgery and partial laryngectomy. Radiother Oncol 1999, 53:1-13.

90. van Loon Y, Sjögren EV, Langeveld TP, Baatenburg de Jong RJ, Schoones JW, van Rossum MA: Functional outcomes after radiotherapy or laser surgery in early glottic carcinoma: a systematic review. Head Neck 2012, 34:1 I79-89.

91. Canis M, Ihler F, Martin A, Wolff HA, Matthias C, Steiner W: Organ preservation in T4a laryngeal cancer: is transoral laser microsurgery an option? Eur Arch Otorhinolaryngol 2013, 270:2719-27.

92. Canis M, Ihler F, Martin A, Wolff HA, Matthias C, Steiner W: Results of 226 patients with T3 laryngeal carcinoma after treatment with transoral laser microsurgery. Head Neck 2013, 36:652-9.

\section{FlOOOPrime}

\section{RECOMMENDED}

93. Genden EM, O'Malley BW Jr, Weinstein GS, Stucken CL, Selber JC, Rinaldo A, Hockstein NG, Ozer E, Mallet Y, Satava RM, Moore EJ, Silver CE, Ferlito $A$ : Transoral robotic surgery: role in the management of upper aerodigestive tract tumors. Head Neck 20I2, 34:886-93.

94. Vergez S, Lallemant B, Ceruse P, Moriniere S, Aubry K, De Mones E, Benlyazid A, Mallet $Y$ : Initial multi-institutional experience with transoral robotic surgery. Otolaryngol Head Neck Surg 2012, | 47:475-8|.

\section{FlOOOPrime}

RECOMMENDED

95. Shah JP: Patterns of cervical lymph node metastasis from squamous carcinomas of the upper aerodigestive tract. Am J Surg 1990, 160:405-9.

96. Hamoir M, Fievez J, Schmitz S, Velasco D, Lengele B: Extended voice-sparing surgery in selected pyriform sinus carcinoma: techniques and outcomes. Head Neck 2013, 35:1482-9.

97. Schmitz, Machiels JP, Weynand B, Grégoire V, Hamoir M: Results of selective neck dissection in the primary management of head and neck squamous cell carcinoma. Eur Arch Otorhinolaryngol 2009, 266:437-43.

98. Robbins KT, Ferlito A, Shah JP, Hamoir M, Takes RP, Strojan P, Khafif A, Silver CE, Rinaldo A, Medina JE: The evolving role of selective neck dissection for head and neck squamous cell carcinoma. Eur Arch Otorhinolaryngol 2013, 270:1 195-202.

99. Brizel DM, Prosnitz RG, Hunter S, Fisher SR, Clough RL, Downey MA, Scher RL: Necessity for adjuvant neck dissection in setting of concurrent chemoradiation for advanced head-and-neck cancer. Int J Radiat Oncol Biol Phys 2004, 58:1418-23.

100. Argiris A, Stenson KM, Brockstein BE, Mittal BB, Pelzer H, Kies MS, Jayaram P, Portugal L, Wenig BL, Rosen FR, Haraf DJ, Vokes EE: Neck dissection in the combined-modality therapy of patients with locoregionally advanced head and neck cancer. Head Neck 2004, 26:447-55

10I. Hamoir M, Ferlito A, Schmitz S, Hanin FX, Thariat J, Weynand B, Machiels JP, Grégoire V, Robbins KT, Silver CE, Strojan P, Rinaldo A, Corry J, Takes RP: The role of neck dissection in the setting of chemoradiation therapy for head and neck squamous cell carcinoma with advanced neck disease. Oral Oncol 2012, 48:203-10.

102. Robbins KT, Wong FSH, Kumar P, Hartsell WF, Vieira F, Mullins B, Niell HB: Efficacy of targeted chemoradiation and planned selective neck dissection to control bulky nodal disease in advanced head and neck cancer. Arch Otolaryngol Head Neck Surg 1999, 125:670-5.

103. Stenson KM, Huo D, Blair E, Cohen EE, Argiris A, Haraf DJ, Vokes EE: Planned post-chemoradiation neck dissection: significance of radiation dose. Laryngoscope 2006, I 16:33-6.

104. Robbins JT, Doweck I, Samant S, Vieira F: Effectiveness of superselective and selective neck dissection for advanced nodal metastases after chemoradiation. Arch Otolaryngol Head Neck Surg 2005, 131:965-9.

\section{FlOOOPrime} RECOMMENDED

105. Mukhija V, Gupta S, Jacobson AS, Anderson Eloy J, Genden EM: Selective neck dissection following adjuvant therapy for advanced head and neck cancer. Head Neck 2009, 31:183-8.

\section{FlOOOPrime \\ RECOMMENDED}

106. Dhiwakar M, Robbins KT, Vieira F, Rao K, Malone J: Selective neck dissection as an early salvage intervention for clinically persistent nodal disease following chemoradiation. Head Neck 2012, 34:188-93.

\section{FlOOOPrime
RECOMMENDED}

107. Schmitz S, Ang KK, Vermorken J, Haddad R, Suarez C, Wolf GT, Hamoir M, Machiels JP: Targeted therapies for squamous cell carcinoma of the head and neck : current knowledge and future directions. Cancer Treat Rev 2014, 40:390-404. 